DOI: 10.20472/IAC.2018.044.029

\author{
MARTA MATULČÍKOVÁ \\ University of Economics in Bratislava, Slovak Republic \\ DANIELA BREVENÍKOVÁ \\ University of Economics in Bratislava, Slovak Republic
}

\title{
QUALITY OF EDUCATION AND SYSTEMS-BASED EDUCATIONAL EVALUATION
}

\begin{abstract}
:
In the paper we present partial results from the research project no. 014EU-4/2016 "Preparation of content and structure of subjects focused on the development of basic entrepreneurial knowledge and skills of graduates from selected medical study fields". We deal with issues of improvement of education evaluation processes. The core of the paper contains the evaluation models based on the systemic approach, characteristic features and instructions for their application and interview methods in three types of businesses differentiated by size. The research was conducted with 267 respondents from three groups of businesses differentiated by size (number of employees) by means of the questionnaire and interview methods. The purpose of empirical research was to establish the applicability of models of education evaluation. Based on the research results, it is concluded that (based on the respondents' opinion) the evaluation of the benefits of systemic based education in businesses is a great challenge for the future, and it is likely to bring benefits to the efficiency and quality of education in businesses. On the other hand, problems occur mainly in quantifying the benefits of education and are related to the lack of knowledge of indicators that would enable businesses to conduct all the steps of the evaluation process. The issues analyzed in the paper require a deeper elaboration from theoretical aspect, which would facilitate its application in practice.
\end{abstract}

\section{Keywords:}

Education evaluation, Education programme, Evaluation model, Quality, Systemic approach to education evaluation, CIP model, IPO model, TVS model.

JEL Classification: 100, 121 


\section{Introduction}

Nowadays, at the time of the internationally integrated economy, building a knowledgebased society is the key pillar of development and the quality of education. Quality as a concept has historically evolved (Vodák, 2005) as an idea of perception of and expectations from final outputs or services that can be identified as the end result. Even in the second half of the 20th century, the quality product was considered the one that complied with predefined parameters, while the characteristics and output parameters were determined by the producer. Under the conditions of competition, only those can succeed who are able to meet the expectations of their customers and attract their clients with the quality of their services. An important role in fulfilling the requirements of both the customers and the learners is the process of education evaluation. Effective employee training leads not only to employee development but also to the prosperity of the business concerned. The process of evaluating education (Kolibová, 2006) enables to identify the effectiveness and meaningfulness of the investments. This is why businesses are concerned with education appraisal issues although it is sometimes very challenging, since it is not possible to completely separate the benefits of education from other factors that make it possible to improve business processes and achieve favourable results. The following strategic approaches to education evaluation are currently considered by businesses (Náhlovský, 2007):

- Perceiving evaluation as a continuous process, i.e. to implement it before, during and after education, rather than just as some questionnaire ritual at the end of educational activities;

- Keeping in mind the sense of the main aim of education, to know what we really have to evaluate;

- Evaluating educational activity according to specific and individual needs of employees, taking into account the functional or occupational classification of employees;

- Informing managers about the evaluation system and determining the responsibility for its implementation. It is important to identify specific people, who will look at the learning appraisal, and assess what aspects to follow, how to use the results, and motivate them to elaborate and refine the evaluation system. If the evaluation is to be effective, it should influence the entire process of implementing the training, i.e. ranging from the planning, preparation up to the implementation process itself. Likewise, the education to be effective for improving work processes, it has to be based on a systemic approach, and the evaluation of education should also apply a systemic approach. 
Corporate education is currently viewed as one of significant personnel functions. Evaluation of the quality of employees creates an objective image of the need for its adequate planning and implementation for the organization's top management.

In view of the current need for quality human resources and in order to maintain an organization's position on the market, efficient education has to be secured, and adequate models of education evaluation need to be applied for this purpose. In the paper we present partial results from the KEGA project no. 014EU-4/2016 "Preparation of content and structure of subjects focused on the development of basic entrepreneurial knowledge and skills of graduates from selected medical study fields". We deal with issues of improvement of education evaluation processes. The core of the paper contains the evaluation models based on the systemic approach, their characteristic features and instructions for their application.

\section{Theoretical starting-points of evaluating education and description of evaluation models based on systemic approach}

Evaluation of education is linked to the final stage of the education process. The intention is to assess the achievement of the planned goals. In the course of plan development, rules and policies are created that will be used for the evaluation of learning outcomes. The product of the educational process contains two categories of outputs (Prúcha, 2009):

1. Educational results - i.e. the immediate changes in the learners created by certain curricular content. The learning outcomes can be measured, rated, evaluated, i.e. be diagnosed at the time they emerge. They come in the form of: - cognitive properties (knowledge, changes in the individual's intellectual level); - cognitive-motor properties (sensomotoric, communication, and work skills); - cognitive-affective features (interests, beliefs, cultural patterns, value orientation, etc.).

2. Effects of education - i.e. consequences or effects caused by learners in society through educational outcomes. The effects of education, unlike the results, have a longterm, sometimes lifelong character. The effect of education is reflected in the way and extent of using the results of education in professional and personal life (Prúcha, 1997). The effects of education are most often perceived as economic effects - effects that can be measured and evaluated, i.e. to track their impact on economic processes. Hamblin (Hamblin, 1974) describes the evaluation of education as any attempt to obtain the feedback on the effects of a particular education programme and to appreciate the value of such education (Eseryel, 2002). Measurement of learning outcomes can be challenging, very closely related to how objectives have been set, their measurability, and how we obtain information about the learning outcomes and the definition of the level at which education will be evaluated. When considering the effects of education, 
consideration should also be given to the non-economic effects of education. These are manifested in the behaviour and actions of man, in man's value orientation, in efforts for self-improvement, including the interest in lifelong education and learning, in efforts for exploring and transforming the surrounding world and oneself. The non-economic effects of education also have a positive impact on economic effects.

In the context of adult learning, where specific benefits from lifelong learning are also expected, several models of education evaluation have been developed.

From the application point of view, two sets of evaluation models of corporate education have been developed, namely target-based evaluation models (Kirkpatrick, 2006 and Phillips, 2011), and evaluation models based on a systemic approach (Eseryel, 2002), which are being developed by other authors (Tenkl, 2014). We focus briefly on the characteristics of these two groups: $\begin{array}{lllll}\text { A. Evaluation } & \text { based } & \text { on } & \text { the } & \text { objectives, } \\ \text { B. Evaluation } & \text { based } & \text { on } & \text { system } & \text { approach. }\end{array}$

In our paper, we will deal with education assessments based on a system approach. The evaluation based on the systemic approach, completed by Eseryel (2002) and subsequently elaborated by other authors, is becoming one of the possible approaches applied in the evaluation of education. A. M. Zinovieff (Zinovieff, 2008) states that the evaluation using a systemic approach focuses on evaluating the effectiveness and efficiency of education in a system context. The disadvantage of evaluation models based on the systemic approach is that these models fail to provide a description of the process, procedures, and evaluation tools. Three basic models can be mentioned among modelling systems based on the systemic approach:

I. Context, Input, Process, Product, CIPP model;

II. Input, Process, Output, Outcome model. IPO model;

III. Training Validation System, TVS model. 


\section{Tab. 1: Evaluation models based on a systemic approach}

\begin{tabular}{|c|c|c|}
\hline odel & O model & TVS model \\
\hline $\begin{array}{l}\text { - It serves for a } \\
\text { comprehensive evaluation } \\
\text { of education programs at } \\
\text { the stage of their } \\
\text { preparation and } \\
\text { implementation. } \\
\text { - The evaluation is ongoing } \\
\text { throughout the training and } \\
\text { education. } \\
\text { - While using this method, } \\
\text { businesses can detect } \\
\text { inappropriately selected } \\
\text { aims in time. } \\
\text { - The CIPP model, } \\
\text { selects a specific training } \\
\text { strategy, as mneeded, then } \\
\text { evaluates to what extent } \\
\text { the programme has been } \\
\text { implemented, and the } \\
\text { results are presented and }\end{array}$ & $\begin{array}{l}\text { - The IPO } \\
\text { abbreviation is a set of } \\
\text { initial letters of English } \\
\text { expressions Input, } \\
\text { Process, Output, while also } \\
\text { Outcomes may be } \\
\text { included here (results from } \\
\text { the long-term view). } \\
-\quad \text { Model IPO model is } \\
\text { used by the IBM company, } \\
\text { which uses it for monitoring } \\
\text { the progress of employees } \\
\text { by setting indicators of } \\
\text { performance in each stage: } \\
\text { input, process, and output. }\end{array}$ & $\begin{array}{l}- \text { The name of the } \\
\text { model in itself Training } \\
\text { Validation } \\
\text { indicates System } \\
\text { implementation the } \\
\text { a systemic approach in } \\
\text { education. } \\
-\quad \text { Separate parts of } \\
\text { the model characterize } \\
\text { three important moments } \\
\text { in the preparation of } \\
\text { education: } \\
\text { identification of the } \\
\text { problem, } \\
\text { identification of } \\
\text { causes, } \\
\text { identification of } \\
\text { benefits in words and in } \\
\text { terms of finance. }\end{array}$ \\
\hline
\end{tabular}

Sources: ZINOVIEFF A. M.: Review and analysis of training impact evaluation methods, and proposed measures to support a United Nations system fellowships evaluation framework prepared. Geneva: WHO's Department of. Human Resources for Health. 2008. p. 19. Retrieved from: http://studylib.net/doc/8208760/review-and-analysis-of-training-impact-evaluation-methods.

\section{CIPP model}

CIPP model developed by D. Stufflebeam in the year 1971 comprises four aspects of evaluation (Zinovieff, 2008):

- $\quad$ Context - acquiring information needed in planning and setting aims.

- $\quad$ Input - input evaluation is applied in developing the proposal, and it deals with e.g. investigating capacity, sources, and identifying various education strategies, leading to the achievement of required objectives with the highest probability. 
- $\quad$ Process - providing a preliminary feedback, which enables it helps control and evaluate the implementation of education programme.

- $\quad$ Product - accumulating information on the results of education intervention for the evaluation of its benefit and importance.

The model is thus focused on the evaluation system itself, rather than on the aim. It is applied mainly in cases of long-term and repeated education programmes. The focus of the model is on the evaluation of educational needs, while it evaluates broader context of educational projects.

\section{IPO model}

An IPO rating model was published by D. S. Bushnell in 1990. The basis of the IPO model is the setting of performance indicators for each stage of the implementation of education (Zinovieff, 2008). - Input - suitability of materials for education, lecturers' experience, qualification of educated persons,

etc.

- Process - planning, design, proposal, and development of education programmes. - Output - output evaluation - feedback from participants, acquired knowledge and skills, and improved performance at work, i.e. the collection of data on the effects of educational interventions.

- Outcomes - outcome evaluation - the long-term results associated with the final sum total the improvement of the profitability and competitiveness of the organization, customer satisfaction, productivity gains, and the like. Likewise in the case of the previous model, the IPO abbreviation is derived from the initial letters of the English expressions Input, Process, Output. The results are evaluated from a long-term perspective.

\section{TVS model}

The author of the model Fitzenz (Zinovieff, 2008) developed this four-level model similar to Kirkpatrick' s model in the third and fourth levels (Tenkl, 2014), although the model remains to be included in system-oriented evaluation models. The TVS Education Assessment Model (TVS) was developed in 1994.

The TVS abbreviation is derived from the Training Validation System. The model consists of the following steps: 
- $\quad$ Situation analysis - data collection, which is to determine the current level of performance in an organization and define the desired level of future performance before training.

- $\quad$ Intervention - identifying the cause of differences between existing and desirable performance and learning, learning how to solve the problem.

- Impact - assessment of differences identified before and after the education process.

- $\quad$ Value - expressing the change in performance in monetary value; measuring differences in quality, productivity, service or sales, etc.

The TVS model describes the systemic approach in education with focus on validity. Its result is precise and corresponds to a genuine level of knowledge. It is oriented to real performance, identifying disproportions from the performance required and it deals with the problems arisen in education, as long as these problems can be solved via education.

\section{Methodological starting-points and the implementation of empirical research}

In the empirical part of the research, we focused on the evaluation process of education held in businesses. Respondents were human resources with full secondary education ending with a maturita exam and higher education (all three grades). Respondents were selected by random selection, while they had to meet the following predefined criteria: - completed education: full secondary education ending with a school-leaving examination and higher education; - type of professional activity carried out, level of managerial position. The survey was conducted using the interview method and questionnaire method with 267 respondents. Three types of businesses were represented, differentiated by the number of employees:

- $\quad$ respondents from small businesses -52 respondents

- $\quad$ respondents from medium-sized businesses - 80 respondents

- $\quad$ respondents from large businesses - 135 respondents.

The primary data collection was conducted through an interview based on questions from a questionnaire designed in advance. Questionnaires were distributed personally or electronically. The purpose of empirical research was to evaluate the applicability of corporate education evaluation approaches. Research has been more extensive, but we 
focus on the application of systems approach-based evaluation approaches. Investing in education and human resource development is one of the key factors in the growth of productivity and competitiveness of businesses in today's advanced society.

Tab. 2: Approaches to education evaluation in businesses in \%

\begin{tabular}{|l|l|l|l|}
\hline \multirow{2}{*}{ Evaluation model } & \multicolumn{3}{l|}{$\begin{array}{l}\text { Analyzed businesses in terms of the number of } \\
\text { employees }\end{array}$} \\
\cline { 2 - 4 } & $\begin{array}{l}\text { Small business } \\
(52)\end{array}$ & $\begin{array}{l}\text { Medium-sized } \\
\text { business (80) }\end{array}$ & $\begin{array}{l}\text { Large business } \\
(135)\end{array}$ \\
\hline CIPP model & 9 & 13 & 27 \\
\hline IPO model & 7 & 16 & 54 \\
\hline TVS model & 8 & 21 & 49 \\
\hline
\end{tabular}

Source: results of empirical research

Research results indicate that businesses find it difficult to implement all the stages of the given models, as described in Table 3.

Tab. 3: Steps of evaluation models based on the target and systemic approaches

CIPP Model (1987)

1. Context

Acquiring necessary for finding andindicators establishing the educationqualifications programme aims.

$$
\text { IPO Model (1990) }
$$

1. Input TVS Model (1994)

\section{Situation}

information Assessment of performance Data collection to identify system arecurrent performance level in trained, the organization and defining availability, suitability of desirable level of future educational materials, etc.performance before education.

\section{Input} Identifying

\section{Intervention}

\section{Process}

education Planning,

proposal, Identifying

causes

of strategies leading to the development, and delivery of differences between existing achievement of the education programmes. required outcome with the highest probability. and desirable performance and identifying whether education can serve as the solution to the problem.

\section{Process}

3. Output

3. Impact

Evaluation of the Accumulating data on the Evaluating the difference in implementation of theimpacts of educationaldata before and after education programme. interferences. education. 
HAMBLIN, A.C. (1974) Evaluation and Control of Training. Maindenhead: McGraw-Hill Book Company.

KIRKPATRICK, D.L. (2006) Evaluating Training Programs: The Four Levels. San Francisco: BerrettKoehler Publishers.

KOLIBOVÁ, H. (2006) ‘Podnikové vzdělávaní jako konkurenční výhoda’, Vzdelávanie dospelých 3, p. 29.

NÁHLOVSKÝ, P. (2007) ‘Jak měrit efektivitu firemního vzdělávaní?’, Moderní řízení 62(7), 8-10.

PHILLIPS, J. J. (2011) Return on Investment in Training and Performance Improvement Programs. New York: Routledge.

PRŮCHA, J. (1997) Moderní pedagogika. Praha: Portál.

PRŮCHA, J. (2009) Moderní pedagogika. $4^{\text {th }}$ updated and suppl. Edn. Praha: Portál.

VODÁK, J. (2005) 'Vyhodnocovanie investícií v oblasti ludských zdrojov - nástroj zvyšovania výkonnosti firmy', Kvalita 3, 22-27. 